УДК 782.1

DOI https://doi.org/10.31723/2524-0447-2020-30-1-6

\author{
Елена Александровна Стародубцева \\ ORCID: 0000-0003-4609-7955 \\ заслуженная артистка Украины, \\ солистка
}

Одесского национального театра оперы и балета, преподаватель кафедры сольного пения

Одесской национальной академии имени А. В. Неждановой estarodubtseva1@gmail.com

\title{
ОБРАЗ ГРАФИНИ В ОПЕРЕ П. И. ЧАЙКОВСКОГО «ПИКОВАЯ ДАМА»
}

Цель работы - всесторонний анализ образа Графини, созданный авторами оперы «Пиковая дама»- П.И. Чайковским и его либреттистом М.И. Чайковским. Методология исследования опирается на анализ средств вербального и музыкального языков с привлечением литературоведческих и музыковедческих источников. Научная новизна - отсутствие специального исследования, посвящённого всестороннему анализу образа Графини, несмотря на огромное количество музыковедческой и театроведческой литературы, его переосмысление, уточнение характеристик. Уделено внимание и жсизненным прототипам Графини повести А.С. Пушкина, и сравнению образа литературного первоисточника с оперным. Практическое значение данного исследования состоит в возможности воплощения образа Графини постановщиками оперы и исполнителями в точном соответствии с замыслом авторов произведения, созданного вербальными и музыкальными средствами с огромной силой убедительности и жминенной достоверностью, в противоположность так называемым «режиссёрским» постановкам. Выводы. Проведенный анализ приводит к переосмыслению образа Графини, сложсившегося в научной литературе, и к его углублённой характеристике, что позволяет исполнителю роли трактовать данный персонаж в более точном соответствии с концепцией оперы. Анализ вокальной партии Графини показывает возможность её исполнения предпочтительно контральто, а не мецио-сопрано. Графиня представляется как вполне реалистический персонаж, показанный многогранно, в котором сочетаются различные черты характера, как обусловленные преклонным возрастом, так и свойственные данной личности в соответствии с социальным положением, биографическими особенностями и личными качествами. Таким образом, реальная Графиня в опере не обладает каким-либо негативным оттенком как личность. Образ жее Графини, созданный воображением Германна и существующий только в его сознании, воплощён в его репликах вокальной партии, выразительными темами, проходящими преимущественно в оркестре, и особенно инструментальными средствами, не нуждающимися в наивной сценической иллюстративности; поэтому исполнительнице роли не следует обращать внимания на данную сторону образа.

Ключевые слова: Александр Пушкин, Пётр Чайковский, «Пиковая дама», образ Графини.

Стародубцева Олена Олександрівна, заслужена артистка України, солістка Одеського національного театру опери та балету, викладач кафедри сольного співу Одеської національної академії імені А. В. Нежданової

Образ Графині в опері П. І. Чайковського «Пікова дама»

Мета роботи - усебічний аналіз образу Графині, створений авторами опери «Пікова дама»П. І. Чайковським і його лібретистом М.І. Чайковським. Методологія досліджсення спирається на аналіз засобів вербальної та музичної мов із залученням літературознавчих $і$ музикознавчих джсерел. Наукова новизна - відсутність спеціального дослідження, присвяченого всебічному аналізу образу Графині, незважаючи на величезну кількість музикознавчої та театрознавчої літератури, його переосмислення, уточнення характеристик. Приділено увагу і життєвим прототипам Графині повісті А.С. Пушкіна, і порівнянню образу літературного першоджерела з оперним. Практичне значення даного дослідження полягає в можливості втілення образу Графині постановниками опери та виконавиями точно відповідно до задуму авторів твору, створеного вербальними і музичними засобами з величезною силою переконливості і життевою достовірністю, на противагу так званим «режисерським» постановкам. Висновки. Проведений аналіз приводить до переосмислення образу Графині, сформованого в науковій літературі, та до його поглибленої характеристики. Це дозволяє виконавиці ролі трактувати даного персонажа відповідно до концепції опери. Аналіз вокальної партії Графині показує можсливість іï виконання переважно контральто, а не меццо-сопрано. Графиня представляється як иілком реалістичний персонаж, показаний багатогранно; у ній поєднуються різні риси характеру, як зумовлені похилим віком, а також властиві даній особистості відповідно до соціального становища, біографічних 
особливостей і особистих якостей. Отже, реальна Графиня в опері не має якого-небудь негативного відтінку як особа. Образ же Графині, який створений уявою Германна й існує тільки в його свідомості, утілений його репліках вокальної партії, виразними темами, що проходять переважно в оркестрі, $i$ особливо інструментальними засобами, що не потребують наївної сценічної ілюстративності; тому виконавиці ролі не варто звертати уваги на цей бік образу.

Ключові слова: Олександр Пушкін, Петро Чайковський, «Пікова дама», образ Графині.

Starodubtseva Elena Aleksandrovna, Distinguished Artist of Ukraine, Soloist of Odessa National Opera and Ballet House, Lecturer at the Solo Singing Chair of the Odessa A. V. Nezhdanova National Academy

Characterization of the Countess from P. I. Tchaikovsky opera "Queen of Spades"

Research objective - to make a comprehensive analysis of the Countess image created by the authors of the "Queen of Spades" opera - P.I. Tchaikovsky and his librettist M.I. Tchaikovsky. The methodology of the study is based on the analysis of the means of verbal and musical languages together with the use of the literary and musicological sources. The scientific novelty is due to absence of a special study devoted to the analysis of the Countess image despite a great number of the musicological and theatre studies literature. Attention has also been paid to the life prototypes of the Countess from A.S. Pushkin novels and to the comparison of the literary character of the source material with the opera. The practical value of this study lies in a possibility to visualize the Countess' character by the opera director and performers in exact matching with the intentions of the authors of the musical piece created by verbal and musical means with great persuasion and true to life as contrary to the so-called "director's" stage performance. Conclusions. The conducted analysis results in rethinking of the image of the Countess that has been established in the scientific literature and in its advanced characteristic, which makes it possible for the performer to treat this character closer to the opera concept. Analysis of the voice part of the Countess reveals a possibility to perform it, preferably, by a contralto singer, not by mezzo-soprano. The Countess is represented as a quite realistic character presented multilaterally and combining various character traits that are explained both by declining years and by peculiar traits of this particular personality in accordance with her social status, background features and personal qualities. The character of the Countess created by German's imagination and existing in his consciousness only is embodied in his voice part cues, by expressive themes passing, mainly, in the orchestra and, particularly, by musical instruments that do not require a nanve scenic illustration.

Key words: Aleksandr Pushkin, Piotr Tchaikovsky, "Queen of Spades", characterization of the Countess.

Актуальность темы исследования. Как известно, в настоящее время на оперных сценах господствует так называемая «режиссерская опера», в которой современные режиссеры, зачастую не имея специального образования, именно оперного, значительно искажают концепцию произведения (иногда весьма кардинально), переосмысливают идейное содержание и трактовку персонажей оперы, какими их создали ее авторы - композитор и либреттист. В результате образы действующих лиц искажаются настолько, что они не имеют ничего общего с задуманным авторами оперы. В связи с этим представляется крайне важным анализ образа персонажа, созданного в соответствии с авторским замыслом, опираясь при этом на текст партитуры, что абсолютно необходимо для адекватного сценического воплощения того или иного действующего лица оперы. В этом видится актуальность темы данной статьи, посвященной образу конкретного оперного персонажа.

Цель исследования - всесторонний анализ образа Графини, созданный авторами оперы «Пиковая дама» - П.И. Чайковским и его либреттистом М.И. Чайковским. Для этого необходимо решить следующие задачи: 1) рассмотреть прототипы Графини литературного первоисточника оперы - повести А.С. Пушкина «Пиковая дама»; 2) проанализировать образ Графини в повести А.С. Пушкина; 3) изучить литературоведческую, музыковедческую и театроведческую литературу о «Пиковой даме» - повести и опере; 5) сравнить образы Графини в повести и опере - либретто и музыке; 6) раскрыть драматургическую роль Графини в опере, определить тип ее образа; 7) проанализировать средства воплощения образа Графини в опере в вокальной и оркестровой партиях; 8) выяснить взаимодействие Графини с другими действующими лицами оперы; 9) проанализировать вокальную партию Графини.

На основе проведенного анализа выстраиваются методы сценического воплощения образа, задуманного авторами оперы, постановщиками и исполнителями; в этом и состоит практическое значение данной работы.

Научная новизна статьи заключается, в связи с отсутствием специальных исследований, посвященных анализу образа Графини (несмотря на огромное количество музыковедческой и театроведческой литературы об опере, в которых ему уделяется немало внимания), в его переосмыслении, уточнении характеристик. 
Изложение основного материала. Литературный первоисточник оперы - одноименная повесть А.С. Пушкина, созданная в 1833 г., которую авторы оперы кардинально переосмыслили, создав абсолютно иную концепцию с совершенно другим идейным содержанием. Изменения коснулись всех персонажей повести, но, заметим, в меньшей степени переосмысленной оказалась Графиня. В повести А.С. Пушкина она имеет прототипы реально существовавшие исторические фигуры. Как отмечают исследователи [21, с. 7-8], это, прежде всего, княгиня Наталья Петровна Голицына, урожденная Чернышева (1744-1837/38 гг.), которая еще до замужества некоторое время жила в Париже и была знакома с Людовиком XV, блистая на балах Версаля. Впоследствии, в Петербурге, Голицына была одной из богатейших представительниц высшего сословия, ведя светский образ жизни, давая балы и увлекаясь карточной игрой (в Петербурге Голицыну иначе как «Пиковой дамой» не называли). «Все современники единодушно отмечали крутой надменный нрав княгини, ее характер, лишенный всяких женских слабостей, суровость по отношению к близким. Семья вся трепетала перед княгиней. В высшей степени своенравная, Голицына была надменна с равными ей по положению и приветлива с теми, кого считала ниже себя» [6]. Сам А.С. Пушкин отмечал, что «при дворе нашли сходство между старой графиней и кн. Натальей Петровной и, кажется, не сердятся <...> [18, с. 325].

«Впрочем, - как отмечает А.А. Соловцов, - графиня ${ }^{*}$ имеет прообразом не только княгиню Голицыну. В облик графини Пушкин ввел и черты другой старухи, Н.К. Загряжской» $[21$, с. 8]. Наталья Кирилловна Загряжская (1748-1837 гг.) была женой двоюродного деда Натальи Гончаровой, жены А.С. Пушкина; ее личность часто упоминается в переписке поэта, часто ее посещавшего. Дочь украинского гетмана Кирилла Григорьевича Разумовского, «она была так избалована родителями, что даже в глубокой старости с сожалением приписывала этому баловству свой капризный характер. Умная от природы, с редкими способностями, она рано начала думать и писать по-французски, но зато всю жизнь с трудом говорила и читала на родном языке; даровитая девушка получила блестящее по тому времени образование <...> Пользовалась огромным почетом в высших кругах Петербурга, принимала у себя особ царской фамилии. Держалась Загряжская независимо <...> Она щедро помогала бедным и покровительствовала всем, кто догадывался ее об этом попросить, и ей редко отказывали <...» [9].

До нашего времени дошло свидетельство П.И. Бартенева, который передал разговор друга А.С. Пушкина П.В. Нащокина с автором «Пиковой дамы»: «Нащокин заметил Пушкину, что графиня не похожа на Голицыну, но что в ней больше сходства с Н. Кирилл. Загряжскою, другою старухою <... Пушкин согласился с этим замечанием и отвечал, что ему легче было изобразить Голицыну, чем Загряжскую, у которой характер и привычки были сложнее» [17, с. 642].

В связи с этим подчеркнем, что А.С. Пушкин, создавая образ Графини (в повести ее имя - Анна Федотовна), «слил в этом образе характерные черты нескольких людей» $[21$, c. 8]; добавим, что гениальный поэт и писатель воплотил типичные черты, свойственные властным, капризным и вздорным пожилым особам, обладающими сильными характерами со способностью подчинять своей воле окружающих, вне конкретной эпохи. Показательно, что образ Графини получил развитие, например, в тургеневской барыне из повести «Муму», Кабановой в «Грозе» А.Н. Островского, Марье Дмитриевне Ахросимовой в «Войне и мире» Л.Н. Толстого и в других произведениях (при всем отличии указанных образов от пушкинского). И в наше время актуальность образа Графини проявляется в весьма достаточной мере.

В сугубо реалистической повести А.С. Пушкин характеризует Графиню предельно объективно: «Графиня не имела малейшего притязания на красоту, давно увядшую, но сохраняла все привычки своей молодости, строго следовала модам семидесятых годов (напомним, действие пушкинской повести разворачивается в 1830-е гг., поэтому имеются в виду 70-е гг. XVIII в. - E. C.) и одевалась так же долго, так же старательно, как и шестьдесят лет тому назад <...> Графиня**, конечно, не имела злой души (заметим, этим качеством она отличается от тургеневской барыни и Кабановой - E. C.); но была своенравна, как женщина, избалованная светом, скупа и погружена в холодный эгоизм, как и все старые люди, отлюбившие в свой век и чуждые настоящему <...> У себя принимала она весь город, наблюдая строгий этикет и не узнавая никого в лицо» [17, с. 237-240]. Графиня показана как личность образованная, но ограниченная, ориентированная на культуру 
Запада. Она вся в прошлом, в эпохе Людовика XV и Екатерины II. Чего только стоит ее реплика: «А разве есть русские романы? <...» [17, с. 239] (кстати, для 1830-х гг. реплика графини не так уж бессмысленна, и ее можно рассматривать как имеющую иронический смысл). В сцене же перед приходом к ней в спальню Германа она получает характеристику, свойственную уже предельно старому человеку, вот-вот готовящемуся отойти в иной мир: «Графиня сидела вся желтая, шевеля отвислыми губами, качаясь направо и налево. В мутных глазах ее изображалось совершенное отсутствие мысли <...> [17, с. 249].

Вместе с тем никак нельзя согласиться с мнением известного литературоведа Б. С. Мейлаха, считающего, что графиня изображена в повести А.С. Пушкина «столь отвратительной» [13, с. 635]. Наоборот, она изображена весьма колоритно, и не ее вина в глубокой старости, неизбежно накладывающей естественный отпечаток на человека. Она вовсе не безобразна, как, например, старуха-процентщица в «Преступлении и наказании» Ф.М. Достоевского. Положительные качества у графини, несомненно, имеются. И недаром она окружена определенным вниманием высшего света и различного рода приживалками. Одно то, что она имеет воспитанницу Лизавету Ивановну, говорит

о доброте ее сердца. И А.С. Пушкин без какого-либо негодования изображает ее, с известной долей беззлобной тонкой иронией. Существенно и то, что графиня прощает свою смерть Германну, думая при этом и об устройстве жизни своей воспитанницы: «Прощаю тебе мою смерть, с тем, чтоб ты женился на моей воспитаннице Лизавете Ивановне <...> [17, с. 257]. Эти слова вполне вписываются в характеристику графини, она вполне могла бы так сказать после своей смерти.

Для темы нашей работы существенна достоверность образа графини и высокая степень его типизации. В опере она предстает лишь с незначительными изменениями (на них мы остановимся далее), в отличие от кардинальных различий в трактовке других основных персонажей повести - Германна и Лизаветы Ивановны. Поэтому весьма важно учитывать (особенно для исполнителя) пушкинское изображение графини. Причем это было бы важно и в том случае, если изменения в трактовке образа в опере являлись весьма существенными по сравнению с первоисточником. Как пишет выдающийся артист Е.Е. Нестеренко, «знать литературные источники совершенно необходимо. И не только знать, но и тщательнейшим образом изучить их, потому что только так можно лучше и глубже понять замысел композитора, определить, какие стороны произведения привлекли его, почему он отступил от текста литературного первоисточника, изменил его или использовал лишь какую-либо часть. Но при этом необходимо ставить перед собой задачу интерпретировать музыкальное произведение, вдохновленное литературным, и считать для себя главным автором композитора» [14, с. 35].

Перейдем же к отличиям трактовки Графини в опере по сравнению с повестью А.С. Пушкина. Если в литературном первоисточнике возраст Графини указан точно 87 лет, то в опере она несколько моложе; ей около восьмидесяти, как восклицает Чекалинский [24, с. 93-94]. Но дело не в формальном возрасте. Графиня в опере представлена вовсе не дряхлой старухой. Если пушкинская старуха страдала склерозом, «не узнавая никого в лицо», и чувства ее уже омертвели, то в произведении братьев Чайковских Графиня обладает способностью и обращать внимание на конкретных людей, и оценивать их, а главное - испытывать определенные эмоции. Так, Графиня обратила внимание на Германа, на воздействие его «очей зловещего огня», как она поет в Квинтете в 1-й картине [там же, с. 86-87], охваченная каким-то непонятным ей страхом. Ее вокальная партия в Квинтете содержит активные восходящие скачки на октаву и сексты, достигая верхних нот ее партии - ре и ми второй октавы (кстати, самой верхней ноты ее партии - в фразе «Зачем опять он предо мной?» [там же, с. 86]); отметим также восклицание Графини с восходящими скачками на квинту и сексту в фразах «Откуда взялся он? Какой он страшный!» по отношению к Герману [там же, с. 88]. Эти скачки свидетельствуют об определенной жизненной энергии и силе характера. В дальнейшем эти же качества Графини постоянно обнаруживаются во многих ее репликах, имеющих характеров повелительных возгласов: «Лиза, отвори» [там же, с. 200], «Зачем балкон открыт?» [там же, с. 202], «Смотри ты! Не дури! Сейчас ложиться!» [там же, с. 202-203], «Сейчас ложись!» [там же, с. 204] из 2-й картины, «Полно врать вам! <...>» [там же, с. 377], «Чего вы тут стоите? Вон ступайте!» [там же, с. 385] из 4-й картины. Эти реплики основаны на нисходящем движении, то скачкообразном (часто на квинту), то постепен- 
ном, что свойственно вообще повелительным интонациям и показывает еще далеко не последнюю степень дряхлости.

Отличия «оперной» Графини от пушкинской верно подметила Н.В. Туманина: «Другим стал в опере и образ графини. Пушкин с замечательным реализмом обрисовал графиню*, обломок прошлого века, причудливую и капризную старую барыню-крепостницу. Образ графини $<\ldots>>$ в повести складывается из ряда мастерски подобранных деталей. Скупо, но со скульптурной точностью вылеплен страшный образ разрушенного временем человеческого существа в эпизоде возвращения графини с бала» [22, с. 200]. Как видим, в опере образ Графини несколько иной, хотя общие черты остались: социальное положение, биография, свойства характера, обусловленные как ее статусом в обществе, так и старостью, с присущей ей капризностью и, зачастую, властностью. Общим является и то, что Графиня фактически осталась жить в прошлой эпохе, времени ее молодости, не принимая реалии настоящего.

Великолепный портрет Графини в молодости рисует Томский (возможно, внук Графини, как и в повести, но это по либретто остается неясным, однако подробности, на которых он останавливается в своем рассказе о Графине, свидетельствуют о его вероятно родственной близости к ней; однако обращение Графини к Томскому на «вы» - в реплике «Скажите (выделено мною - E. C.) мне, кто этот офицер?» [24. с. 88] - ставит версию о том, что это ее внук, под большое сомнение; к внуку, особенно учитывая характер Графини, она бы обращалась, очевидно, на «ты», как к Лизе; да и Томский вряд ли обратился бы к своей бабушке так официально - «Графиня») в своей Балладе из 1-й картины и речитативе, предшествующем ей, в которой предстает блестящая красавица («Венера московская!» [там же, с. 94]), светская львица, подверженная страстям (кстати, так же, как и Герман, - в этом проявляется родственность их натур!). Так, она, судя по рассказу Томского, «все ночи напролет играла красавица» [там же, с. 95] (сравним с репликой Сурина о Германе: «Был и, как всегда, с восьми и до восьми утра, прикован к игорному столу» [там же, с. 40]. Гордость Графини выражена в ее возгласе - ответе Сен-Жермену на его нескромное предложение - «Как смеете вы?» с восходящим квинтовым скачком и пролонгированием слога «как» [там же, с. 99], но она погасила ее стремлением к возможности отыграться. Таким образом, в Балладе Томского Графиня обрисована как эксцентричная особа, в высшей степени азартная, страстная, до известной степени гордая, увлекающаяся, вызывающая интерес к своей личности.

Основная особенность образа Графини в опере заключается в том, что она показана не только объективно, какой она есть на самом деле, в реалистическом плане, а и такой, какой ее воспринимает Герман, то есть ее облик в значительной степени вырисовывается сквозь призму восприятия главного героя оперы, субъективно. На это обращают внимание ряд исследователей [20, с. 109-110; 22, с. 201]. Подчеркнем, что образ Графини в сознании Германа формируется только музыкальными средствами, в либретто эта особенность только намечена.

Объективно Графиня показана только в двух эпизодах: в 1-й картине в Квинтете «Мне страшно» и небольшом диалоге с Томским и в 4-й картине, где в основном и создается ее образ. Во 2-й картине ее объективная характеристика дана только в либретто, а в 5-й и 7-й картинах при появлении призрака, естественно, только в воображении Германа.

Вначале остановимся на объективной характеристике образа. В 1-й картине при встрече с Германом Графине представляется он страшным, о чем мы уже упоминали. Причина появления этого чувства, как мы полагаем, вполне объяснима: Графиня, благодаря своему внутреннему сходству с Германом по типу личности (на что мы уже обращали внимание), инстинктивно, подсознательно, только по горению его взгляда почувствовала одержимость его натуры, способность идти до конца вопреки здравому смыслу и обстоятельствам, силу характера, и это ее пугает.

Страх у Графини, вызываемый незнакомым ей офицером (как видим, вполне объяснимый реалистически), в значительной степени усилил, конечно, ее ужас при появлении Германа у себя в спальне в 4-й картине. Это чувство указывает на особую впечатлительность Графини и силу ее воображения.

Во 2-й картине реплики Графини, воплощенные в ее вокальной партии, вполне естественны для данной ситуации, учитывая характер старухи: услышав шум в комнате внучки, Графиня решила выяснить, в чем дело, и всячески распекает молодую девушку. Даже 
в том, что Лизе «не спится», Графиня обвиняет «времена»: «Не спится! <...>, - передразнивает бабушка внучку. - Слыхано ли это? Ну, времена!» [24, с. 203]. Повелительные и сердитые вокальные фразы Графини мы уже отмечали; однако старуха отходчива: реплика «А я-то слышу шум; ты бабушку тревожишь!» [там же, с. 204] с понижением тесситуры и речитацией на одном звуке свидетельствует о «потеплении» в отношении бабушки к своей внучке и даже проявлении некоторой любви к ней. Последняя ее реплика перед уходом «и глупостей не смей тут затевать!» [там же, с. 204-205] достаточно спокойна; она звучит без какой-либо угрозы. Однако оркестровая партия в этой сцене создает совершенно иной образ, каким он представляется Герману (об этом речь впереди).

Сцене Графини в 4-й картине исследователи оперы уделяют, казалось бы, достаточное внимание $[1$, с. $389-396 ; 2$, с. $752-765 ; 3$, с. $174-178 ; 7$, с. $184-194 ; 12$, с. $205 ; 16$, с. 306-313; 20 , с. $110-111 ; 21$, с. 114-127; 22, с. 216-220; 25, с. 95], однако далеко не все детали данной сцены, играющие существенную роль в создании образа, раскрыты в должной мере. Проанализируем ее более подробно.

Монологическая Сцена Графини, начиная с первой ее реплики до полного погружения в сон, состоит из четырех разделов, неравных по протяженности, но достаточно индивидуальных и контрастных друг другу: 1) выражение крайней степени раздражения и усталости после утомительного для старухи бала; 2) критики современных нравов; 3) воспоминания о молодости («воспоминания мертвеца», «мемуары», как удачно назвал их Б.В. Асафьев («жуткие подлинные мемуары XVIII века, впервые обнародованные в музыке» [3, с. 176]); 4) песенка, основанная, как известно, на арии Лоретты из оперы А. Гретри «Ричард Львиное Сердце».

Первый раздел открывается репликой Графини «Полно врать вам! < .. > Надоели! < ..>» [24, с. 377] с характерным квинтовым нисходящим скачком, выражающей раздражение старухи, вполне отдающей себе отчет в смысле грубой лести приживалок. Оркестр в этот момент значительно подчеркивает данную эмоцию пожилой женщины: звучат тройные форшлаги в партиях первых скрипок и струнных басов с последующими нисходящими ходами, а в партиях вторых скрипок и альтов - характерный ритмический рисунок, основанный на неоднократном сопоставлении триоли шестнадцатыми и восьмой, приобретающий значение лейтритма Графини (впервые появляется во 2-й картине при появлении ее на сцене, а затем в 4-й картине при ее выходе, служа фоном Хора приживалок); этот ритм звучит на протяжении всего первого раздела.

Далее, фразы «Я устала! <..> мочи нет <...> [там же, с. 378] звучат в самой низкой тесситуре партии Графини с нисходящим квинтовым скачком к самой низкой ноте в ее партии - ля малой октавы, что демонстрирует усталость старухи в самой полной мере. Нежелание Графини спать в постели можно объяснить не только как пустой каприз, но и как подсознательное сопротивление смерти, после которой тело человека принимает лежачее положение, поэтому столь пожилая женщина желает спать в кресле. Вступление басового кларнета с нисходящей линией в большой степени усиливает мрачный колорит и создает угнетающее настроение; в этом отношении «помогают» бас-кларнету фагот и флейта в низком регистре, исполняющие основную интонацию предшествовавшего Хора приживалок; затем настойчивое долбящее ostinato флейты и обоих фаготов в три октавы драматизируют и без того крайне гнетущую обстановку, предваряя прием, ставший столь популярным в XX в. [там же, с. 378-379].

Если в данном разделе благодаря указанным оркестровым средствам (лейтритм, темный колорит) воплощаются особенности восприятия Графини Германом и предвещаются последующие драматические события, то в следующем разделе старуха представлена совершенно объективно. Второй раздел открывает восклицание Графини «Ах, постыл мне этот свет!» [там же, с. 379]. Оно основано на нисходящем гаммообразном движении, типичном для некоторых тем П.И. Чайковского, выражающих ностальгические чувства и трагическую обреченность (например, «Что день грядущий мне готовит» из арии Ленского в опере «Евгений Онегин», Adagio из «Щелкунчика» - танец феи Драже и принца Коклюша). В данном случае ностальгия по давно прошедшим годам выражена у Графини в высшей степени ярко. Указанная тема переходит из вокальной партии в оркестр, где ее вариант поочередно проводят сначала меланхолический фагот, а затем первые и вторые скрипки в октаву, создавая в некоторой степени просветление и выражая иронию, впрочем, вполне благодушную. В это время Графиня опять сетует на «времена» (вспомним ее реплику из 
2-й картины), возмущаясь манерами и тоном современного светского общества. Остинатное проведение темы в оркестре симфонизирует данный эпизод, являясь показательным приемом для П.И. Чайковского: речитатив вокальной партии сопровождается развитой, тематически насыщенной оркестровой, создавая тем самым второй план. Возмущенные и выражающие презрение реплики Графини «Кто дансерки?» (тонкость либретто - употребление французского слова, также как и предыдущее выражение «ни петь не знают» - по-русски следовало бы сказать «не умеют», в которых заключается игра слов: по-французски глаголы «уметь» и «знают» выражаются одним словом - savoir, на что указывает Л.Э. Красинская: Графиня привыкла «говорить и думать по-французски» [12, с. 205]), «Кто поет? Девчонки!» [24, с. 380]: основаны на указанном уже нами нисходящем квинтовом скачке, придавая единство всей ее вокальной партии. В то же время в скрипичных партиях также звучат нисходящие квинтовые ходы. Таким образом, создается единство вокальной и оркестровой партий (при всем их различии! - дублирование вокальной партии инструментами отсутствует), углубляя воплощаемый образ.

В третьем разделе Сцены Графиня погружается в сладостные для нее воспоминания о временах своей молодости. Характер вокальных фраз разительно изменяется. Появляется некоторая задушевность и мягкость в интонациях. Юмористический эффект возникает при упоминании знаменитой фаворитки Людовика XV: «сама, сама маркиза Помпадур! <...> [там же, с. 382]: ее имя Графиня произносит на одной из самых высоких нот ее партии - на ре второй октавы (для Графини маркиза является несомненным авторитетом, фактически управляющим в то время государством); в результате тесситурного выделения возникает ироническое отношение автора оперы к своему персонажу; вот где тесситура является ярким выразительным средством! Слово «король» произносится на гораздо более низких нотах [там же, с. 383].

И в этом разделе роль оркестра очень значительна. Вначале у кларнета звучат протяженные звуки с последующими новемолями в низком регистре, создавая тусклый колорит (ведь все в прошлом!). К нему присоединяются басовый кларнет и валторна с сурдиной, усиливая мрачную звуковую окраску (вот где ярко проявляется мастерство П.И. Чайковского как блестящего психолога-колориста!); одновременно начинают шелестеть скрипки, исполняя tremolo на три рiano, виолончели pizzicato мягко отмечают сильные доли. В результате создается многоплановая звуковая картина, как нельзя более точно отображающая погружение в далекие, неуловимые и столь сладостные воспоминания. На словах «При них я и певала <...> английский рожок, также приобретающий в данном случае ностальгический оттенок, печально, но вместе с тем задушевно интонирует старинную французскую песню "Vive Henri IV" (тему этой песни П.И. Чайковский использовал в «Спящей красавице», где она звучит совсем иначе - торжественно и помпезно). Шелестящий пассаж первых скрипок, также на три ріano, завершает этот эпизод, подчеркивая зыбкость событий, оставшихся только в достаточно цепкой памяти Графини («Я, как теперь, все вижу <...> [там же, с. 383]).

Четвертый раздел сцены - напевание Графиней мелодии упомянутой уже нами арии Лоретты. Об ее отличиях от оригинала написана обстоятельная статья Л.В. Карагичевой [10], поэтому мы не останавливаемся на характеристике песенки Графини в опере; скажем только, что она в высшей степени удачно воплощает состояние пожилой женщины, с ностальгией вспоминающей молодые годы и постепенно погружающейся в сон, поэтому допущенный П.И. Чайковским анахронизм никакой роли не играет, так как художественный эффект его полностью нивелирует. Возглас Графини «Чего вы тут стоите? Вон ступайте!» вполне в духе ее повелительных реплик в раздраженном состоянии; отметим только, что первая фраза реплики интонационно совпадает с началом темы Германа «Я имени ее не знаю», предвещая таким образом неумолимо приближающуюся роковую развязку.

Третий и четвертый разделы сцены вносят существенно новую черту в характеристику Графини, показывая ее с совершенно иной стороны - лирической. Перед нами предстает старая женщина, вспоминающая безвозвратно ушедшие юные годы, и этим она вызывает сочувствие.

В сцене с Германом состояние Графини передает только оркестр, партия которого отображает ужас, охвативший старуху при виде того офицера, к которому она подсознательно испытывала страх. Кларнеты и фаготы передают оцепенение и судорожное биение ее сердца. П.И. Чайковский абсолютно точно в медицинском смысле передает сердечную аритмию с 
помощью синкопированных ритмических рисунков и форшлагов в партиях этих инструментов. Но Графиня после настойчивого призыва Германа «Откройтесь мне! Скажите!» находит в себе силы выпрямиться и грозно смотреть на него согласно ремарке либретто [24, с. 399-400]. И ее ответ звучит в оркестре: громогласно его проводят духовые инструменты с преобладаем медных - трубы и тромбона [там же, с. 400-401]. В самый последний момент своей жизни Графиня проявляет мужество, отказывая Герману в ответе, выраженном словами: ее грозное молчание и является ответом. Это кульминационный момент во взаимоотношениях Графини и Германа, приводящий к смерти старухи. В то же время это проявление рока, связывающего персонажей (в этом смысле рок - это маниакальная одержимость Германа, приводящая его не только к собственной гибели, но и Графини и Лизы).

Момент смерти Графини также обозначен с медицинской точностью: ее кратковременная агония и последние удары сердца передают эти же фигурации кларнетов и фаготов с заключительными аккордами труб и тромбонов [там же, с. 404-405], что отмечено рядом исследователей [3, с. 177; 7, с. 192; 16, с. 312; 22, с. 219-202].

Характеристика Призрака Графини в 5-й и 7-й картинах не входит в задачу нашей работы, так как он существует только в воображении Германа.

Таким образом, у реальной Графини нет своей лейттемы, ее характеристика складывается из речитативных реплик, отличающихся чрезвычайной выразительностью и точностью обрисовки образа, то основанных на повелительных выкриках, то напевных (в этом отношении П.И. Чайковский проявляет незаурядное мастерство, ставящее его в ряд изумительных Мастеров речитатива - А.С. Даргомыжского и М.П. Мусоргского), и песенной мелодии А. Гретри; помимо этой песни яркие кантлиенные тематически содержательные темы в партии Графини отсутствуют. Партия Графини в основном диатонична в своей основе, сочетая как поступенное движение и речитацию на одном звуке, так и скачки, но не более октавы.

Что же касается темы, основанной на трехзвучном мотиве, развиваемом секвенционно и называемом иногда темой Графини (так назвал ее Б.В. Асафьев [3, с. 166-167], что утвердилось в работах некоторых авторов и в учебной практике $[1$, с. $368 ; 11$, с. 178 ; 15 , с. $276 ; 16$, с. $280 ; 19$, с. $185 ; 20$, с. $110 ; 22$, с. $202 ; 23$, с. 116$])$, то к реальному персонажу эта тема не имеет никакого отношения: можно сказать - это тема Графини только в воображении Германа, а точнее, как называет ее А.Н. Должанский, это «тема судьбы», «тема азартного, опасного риска» [8, с. 169]. Графиня, созданная воспаленным воображением Германа, характеризуется только его репликами и оркестром, приобретающим огромную выразительную силу (рамки нашей работы не позволяют на этом остановиться, да это и не входит в задачи данной статьи $-E$. $C$.). Исходя из этого, никакой двойственности, как пишут некоторые исследователи [4, с. 116; 5, с. 83; 20, с. 109-110; 23, с. 317; 19, с. 184, 186], в образе Графини не наблюдается: это вполне цельный, реалистический образ, и нет никаких оснований считать его хоть в какой-то мере негативным: Графиня показана со всеми ее недостатками, во многом обусловленными весьма почтенным возрастом, но в то же время, как мы показали, и некоторыми достоинствами.

Как обозначено в клавире и партитуры оперы, партия Графини написана для меццо-сопрано. Однако, учитывая диапазон партии $\left(\mathrm{a}-\mathrm{e}^{2}\right)$ и ее относительно низкую тесситуру, скорее всего партия предназначена для контральто, что подтверждается опытом оперной практики: партию успешно исполняют как контральто, так и меццо-сопрано. В уже упомянутых нами репликах «Сама маркиза Помпадур! <...>» и «Лиза, отвори!» невысокие для меццо-сопрано ноты $\mathrm{d}^{2}$ и еs ${ }^{2}$ должны в связи с их смыслом восприниматься как высокие, что естественно будет звучать именно у контральто. Встречающиеся в партии Графини звуки малой октавы $(\mathrm{h}, \mathrm{b}, \mathrm{a})$ должны звучать достаточно тембрально насыщенно и вполне естественно, что также обеспечивает контральто. Песня же Графини звучит в диапазоне ais - $\mathrm{g}^{1}$, то есть в низкой тесситуре, естественной именно для контральто.

Основной же вывод для исполнителей роли Графини заключается в том, что, работая над сценическим воплощением роли, следует, конечно, выстраивать ее исходя из реального образа данного персонажа, созданного авторами оперы вербальными и музыкальными средствами с огромной силой убедительности и жизненной достоверностью. Образ же Графини, созданный воображением Германа и существующий только в его сознании, воплощен в его репликах вокальной партии и особенно оркестровыми средствами, не нуждающимися в наивной сценической иллюстративности. 


\section{СПИСОК ЛИТЕРАТУРЫ}

1. Аверьянова О.И., Орлова Е. П.И. Чайковский. Русская музыкальная литература. Вып. 3. Учебное пособие для музыкальных училищ. Москва : Музыка, 2013. С. 208-463.

2. Альшванг А.А. П.И. Чайковский. 2-е изд. Москва : Музыка, 1967. 928 с.

3. Асафьев Б.В. «Пиковая дама». Симфонические этюды / Б. Асафьев. Ленинград : Музыка, 1970. C. $158-193$.

4. Берлянд-Черная Е.С. Пушкин и Чайковский. Москва : Музгиз, 1950. 144 с.

5. Богданов-Березовский В.М. Оперное и балетное творчество Чайковского : очерки. Ленинград ; Москва : Гос. изд-во «Искусство», 1940. 119 с.

6. Голицына Наталья Петровна. URL: https://ru.wikipedia.org/wiki/\%D0\%93\%D0\%BE\%D0\%BB\% D0\%B8\%D1\%86\%D1\%8B\%D0\%BD\%D0\%B0, \%D0\%9D\%D0\%B0\%D1\%82\%D0\%B0\%D0\%BB\%D1\% $8 \mathrm{C} \% \mathrm{D} 1 \% 8 \mathrm{~F} \% \mathrm{D} 0 \% 9 \mathrm{~F} \% \mathrm{D} 0 \% \mathrm{~B} 5 \% \mathrm{D} 1 \% 82 \% \mathrm{D} 1 \% 80 \% \mathrm{D} 0 \% \mathrm{BE} \% \mathrm{D} 0 \% \mathrm{~B} 2 \% \mathrm{D} 0 \% \mathrm{BD} \% \mathrm{D} 0 \% \mathrm{~B} 0$ (дата обращения: $20.0 \overline{5} .2020)$.

7. Густякова Д.Ю. Классический оперный текст в современной культуре: «Пиковая дама» П.И. Чайковского : дис. ... канд. искусствоведения: 24.00.01. Ярославль, 2006. 228 с.

8. Должанский А.Н. Еще о «Пиковой даме» и Шестой симфонии Чайковского. Избранные статьи. Ленинград : Музыка, 1973. С. 162-177.

9. Загряжская Наталья Кирилловна. URL: https://ru.wikipedia.org/wiki/\%D0\%97\%D0\%B0\%D 0\%B3\%D1\%80\%D1\%8F\% D0\%B6\%D1\%81\% D0\%BA\%D0\%B0\%D1\%8F, \% D0\%9D\%D0\%B0\%D1 \%82\%D0\%B0\%D0\%BB\%D1\%8C\%D1\%8F_\%D0\%9A\%D0\%B8\%D1\%80\% $\mathrm{D} 0 \% \mathrm{~B} 8 \% \mathrm{D} 0 \% \mathrm{BB} \% \mathrm{D} 0 \% \mathrm{~B}-$ B\% D0\% BE\% D0\%B2\% D0\% BD\%D0\%B0 (дата обращения: 20.05.2020).

10. Карагичева Л.В. Два этюда о «Пиковой даме». Советская музыка. 1990. № 6. С. 50-53.

11.Келдыш Ю.В. П.И. Чайковский. История русской музыки : в 10-ти томах. Москва : Музыка, 1994. Т. $8: 70-80$-е гг. XIX в. Ч. 2. С. 89-245.

12.Красинская Л.Э. Оперная мелодика П.И. Чайковского. Ленинград : Музыка, 1986. 248 с.

13. Мейлах Б.С. Пушкин и его эпоха. Москва : Гос. изд-во художественной литературы, 1958. 699 с.

14.Нестеренко Е.Е. Размышления о профессии. Москва : Искусство, 1985. 184 с.

15.Побережная Г.И. Петр Ильич Чайковский. Киев, 1994. 347 с.

16. Протопопов В.В., Туманина Н.В. Оперное творчество Чайковского. Москва : Изд-во Академии Наук СССР, 1957. 372 с.

17.Пушкин А.С. Пиковая дама. Собрание сочинений : в 10-ти т. / А.С. Пушкин. Москва : Гос. изд-во художественной литературы, 1960. Т. 5 : Романы. Повести. С. 233-262.

18.Пушкин А.С. Дневник. Собрание сочинений : в 10-ти т. / А.С. Пушкин. Москва : Гос. изд-во художественной литературы, 1962. Т. 7. С. 312-343.

19. Розанова Ю.А. История русской музыки. Москва : Музыка, 1986. Т. ІІ : Вторая половина XIX в. Кн. 3-я : П.И. Чайковский. 2-е изд., испр. и доп. 279 с.

20. Ручьевская Е.А. Петр Ильич Чайковский. Санкт-Петербург, 2010. 140 с.

21.Соловцов А.А. Пиковая дама П.И. Чайковского. Москва : Музгиз, 1959. 152 с.

22. Туманина Н.В. Чайковский и музыкальный театр. Москва : Музгиз, 1961. 254 с.

23. Туманина Н.В. П.И. Чайковский. Великий мастер. 1878-1993. 2-е изд. Москва : ЛЕНАНД, 2014. $504 \mathrm{c}$.

24. Чайковский П.И. Пиковая дама. Партитура. Москва : Музыка, 1983. 610 с.

25.Ярустовский Б.М. Оперная драматургия Чайковского. Москва ; Ленинград. 1947. 242 с.

\section{REFERENCES}

1. Averyanova O., Orlova E. P.I. (2013) Chajkovskij. Russkaya muzykalnaya literatura. Vyp. 3. Uchebnoe posobie dlya muzykalnyh uchilish. Moskva: Muzyka, S. 208-463[in Russian].

2. Alshvang A. (1967) P.I. Chajkovskij. Izd. 2-e. Moskva: Muzyka [in Russian].

3. Asafev B. (1970) "Pikovaya dama". B. Asafev. Simfonicheskie etyudy. Leningrad: Muzyka, S. 158-193 [in Russian].

4. Berlyand-Chyornaya E. (1950) Pushkin i Chajkovskij. Muzgiz [in Russian].

5. Bogdanov-Berezovskij V. (1940) Opernoe i baletnoe tvorchestvo Chajkovskogo. Ocherki. Leningrad, Moskva: Gos. izd-vo "Iskusstvo" [in Russian].

6. Golicyna, Natalya Petrovna. URL: https://ru.wikipedia.org/wiki/\%D0\%93\%D0\%BE\%D0\%BB\% D0\%B8\%D1\%86\%D1\%8B\%D0\%BD\%D0\%B0, \% D0\%9D\%D0\%B0\%D1\%82\%D0\%B0\%D0\%BB\%D $1 \% 8 \mathrm{C} \% \mathrm{D} 1 \% 8 \mathrm{~F} \% \mathrm{D} 0 \% 9 \mathrm{~F} \% \mathrm{D} 0 \% \mathrm{~B} 5 \% \mathrm{D} 1 \% 82 \% \mathrm{D} 1 \% 80 \% \mathrm{D} 0 \% \mathrm{BE} \% \mathrm{D} 0 \% \mathrm{~B} 2 \% \mathrm{D} 0 \% \mathrm{BD} \% \mathrm{D} 0 \% \mathrm{~B} 0 \quad$ (data obrasheniya: 20.05 .2020 ).

7. Gustyakova D. (2006) Klassicheskij opernyj tekst v sovremennoj kulture: "Pikovaya dama" P.I. Chajkovskogo: a dissertation on the health of the scientific level of the candidate of the mystical exaltation. Yaroslavl [in Russian].

8. Dolzhanskij A. Eshyo o "Pikovoj dame" i Shestoj simfonii Chajkovskogo. A. Dolzhanskij. Izbrannye stati. Leningrad: Muzyka, 1973. S. 162-177 [in Russian].

9. Zagryazhskaya, Natalya Kirillovna. URL: https://ru.wikipedia.org/wiki/\%D0\%97\%D0\%B0\%D0 \%B3\%D1\%80\%D1\%8F\%D0\%B6\%D1\%81\%D0\%BA\%D0\%B0\%D1\%8F,_\%D0\%9\%D0\%B0\%D1\% 
82\%D0\%B0\%D0\%BB\%D1\%8C\%D1\%8F \%D0\%9A\%D0\%B8\%D1\%80\%D0\%B8\%D0\%BB\%D0\%BB\%D0\%BE\%D0\%B2\%D0\%BD\%D0\% B0 (data obrasheniya: 20.05.2020).

10. Karagicheva L. (1990) Dva etyuda o "Pikovoj dame". Sovetskaya muzyka. № 6. S. 50-53[in Russian]. 11.Keldysh Yu. (1994) P.I. Chajkovskij. Istoriya russkoj muzyki: v 10 tomah. Moskva: Muzyka, T. 8: 70-80-e gody XIX veka. Ch. 2. S. 89-245 [in Russian].

12. Krasinskaya L. (1986) Opernaya melodika P.I. Chajkovskogo. Leningrad: Muzyka [in Russian].

13. Mejlah B. (1958) Pushkin i ego epoha. Moskva: Gos. izd-vo hudozhestvennoj literatury [in Russian]. 14. Nesterenko E. (1985) Razmyshleniya o professii. Moskva.: "Iskusstvo" [in Russian].

15. Poberezhnaya G. (1994) Pyotr Ilich Chajkovskij. Kiev [in Russian].

16. Protopopov V., Tumanina N. (1957) Opernoe tvorchestvo Chajkovskogo. Moskva: Izd-vo Akademii Nauk SSSR [in Russian].

17. Pushkin A. (1960) Pikovaya dama. Sobranie sochinenij v 10-ti tomah. Moskva: Gos. izd-vo hudozhestvennoj literatury. T. 5: Romany. Povesti. S. 233-262 [in Russian].

18. Pushkin A. (1962) Dnevnik 1833-1835 gg. Sobranie sochinenij v 10-ti tomah. Moskva: Gos. izd-vo hudozhestvennoj literatury. T. 7. C. 312-343 [in Russian].

19. Rozanova Yu. (1986) Istoriya russkoj muzyki. T. II: Vtoraya polovina XIX veka. Kn. 3-ya: P.I. Chajkovskij. 2-e izd., ispr. i dop. Moskva: Muzyka [in Russian].

20.Ruchevskaya E. (2010) Pyotr Ilich Chajkovskij. Sankt-Peterburg: Kompozitor-Sankt-Peterburg [in Russian].

21.Solovcov A. (1959) Pikovaya dama P. I. Chajkovskogo. Moskva: Muzgiz [in Russian].

22. Tumanina N. (1961) Chajkovskij i muzykalnyj teatr. Moskva: Muzgiz [in Russian].

23.Tumanina N. (2014) P.I. Chajkovskij. Velikij master. 1878-1993. Izd. 2-e. Moskva: LENAND [in Russian].

24. Chaikovskij P. (1983) Pikovaya dama. Partitura. Moskva: Muzyka [in Russian].

25. Yarustovskij B. (1947) Opernaya dramaturgiya Chajkovskogo. Moskva, Leningrad [in Russian].

УДК 782.3

DOI https://doi.org/10.31723/2524-0447-2020-30-1-7

Ганна Олексіївна Савонюк

ORCID: 0000-0001-7005-9583

здобувач кафедри історії музики та музичної етнографіі

Одеської національної музичної академії імені А. В. Нежданової, викладач лічею «Наукова зміна» annasavonyuk@gmail.com

\title{
ПАСІОНИ О. КОЗАРЕНКА: ЖАНРОВИЙ СИНТЕЗ ТРАДИЦІЙНОГО ТА ІННОВАЦІЙНОГО
}

\begin{abstract}
Мета роботи - у дослідженні музично-історичного розвитку пасіонів (від прадавніх часів до сучасності) із жанрово-стильовою акиентуацією на українських страстях. Методологія дослідження спирається на методи індукиії, жсанрово-стильового аналізу, історичний та герменевтичний методи. Наукова новизна полягає в доведенні існування «натяків» на жканр страстей ще в давньоєгипетських міфах. Уперше проведено паралелі від давньоєгипетських образів (Озіріс, Ізіда, єгиптяни) до новозавітних персонажів (Христос, Богоматір, натовп ізраїльтян, шо жадав смерті Ісуса). У дослідженні вперше вказано на феноменологічні особливості сучасної моделі українських пасіонів ( Страсті Господа Бога Нашого Ісуса Христа»), шо з'являється у творчості композитора Олександра Козаренка. Даний твір $\epsilon$ прикладом звернення до пражанру пасіонів, який відроджено через музичне звернення композитора до Острозьких антифонів православної Службои Дванадияти Євангелій (ранньомодерна доба). У творі О. Козаренка майстерно поєднані традиційні й інноваційні аспекти формування пасіонів, що вплинули на формування сучасних ознак жсанру взагалі. Митеиь вдало поєднує стародавні слов'янські наспіви з авторським баченням страстей нашого часу. Висновки. Підкреслено, що розширення мистецького культурного простору завдяки зверненну до жканру пасіонів є нагальною духовною потребою сьогодення. Унікальною творчою одиницею пасіонів початку третього тисячоліття є страсті «по-українські». Пасіони є структурою унікальною, що поєднує в собі поліморфні ознаки. Твір львівського композитора Олександра Козаренка доводить аутентичну неповторність національних витоків та підтверджуе вагомий внесок сучасних українських митиів у світові культуру та мистеитво. Нове композиторське бачення сакрального музичного монодійного мелосу не лише відновило його, але й показало внутрішній потениіал звучання, що довело його актуальність у нашому сьогоденні.
\end{abstract}

Ключові слова: жканр, Ісус, пасіони, страсті. 